\title{
Monetary Policy and Economic Growth in Nigeria: An Autoregressive Distributed Lag (ARDL) Analysis
}

\author{
Victoria Hauwa Ibrahim \\ Department of Economics, Nasarawa State University, \\ Keffi, Nasarawa State, Nigeria.
}

\begin{abstract}
The study assessed the impact of monetary policy on economic growth in Nigeria. Three objectives guided the study. It employed quarterly data spanning 1986:Q12018:Q4, and used the Autoregressive Distributed Lag (ARDL) model, and the Granger causality test to carry out its empirical analysis and achieving its objectives. Findings from the study revealed that the monetary policy rate (MPR) had a positive impact on economic growth, but it was however not statistically significant. The broad money supply $\left(\mathrm{M}_{2}\right)$ as a monetary policy instrument had a much more positive and highly statistically significant impact on economic growth in Nigeria. As such, the study recommended that the CBN should embark on a comprehensive monitoring of monetary instruments and aggregates and place less emphasis on inflation targeting (IT) alone. It is important to use other instruments which the central bank can control effectively like the broad money supply $\left(\mathrm{M}_{2}\right)$ as it is more effective on the economy.
\end{abstract}

Keywords: Monetary policy, Economic growth, Monetary Policy Rate, Broad Money Supply, New Consensus Macroeconomic.

\section{INTRODUCTION}

A sustainably high growth rate of output and a low inflation rate are the two main goals of a majority of macroeconomic policies. Monetary policy plays an important role in developing economies by increasing the growth rate of the economy by influencing the cost and availability of credit, by controlling inflation and maintaining equilibrium in the balance of payments (Chand, 2018). As such, the principal objectives of monetary policy are to control credit for controlling inflation and to stabilize the price level, to stabilize the exchange rate, to achieve equilibrium in the balance of payments, and to promote economic development.

According to the CBN (2018), over the years, the objectives of monetary policy in Nigeria have remained the attainment of internal and external balance of payments. However, emphasis on techniques and instruments to achieve these objectives have changed over the years. There have been two major phases in the pursuit of monetary policy, namely, before and after 1986; the first phase placed emphasis on direct monetary controls, while the second relies on market mechanisms. Some of the policy instruments used in monetary policy operation in the country are the Monetary Policy Rate (MPR), and other intervention instruments such as the Open Market Operations (OMO), Discount Window Operations, Cash Reserve Ratio (CRR) and the Foreign Exchange Net Open Position (NOP) limit.

Modern design of monetary policy has followed the proposition of the New Consensus Macroeconomics (NCM). The basic principle of the NCM is the use of short-term interest rate to achieve price-stability (Meyer, 2001; Arestis, 2007). The objective of price-stability is centered on the supply-side equilibrium and the inability of monetary policy to have any long-run impact on real variables (Bean, 2007; Fontana, 2009). Thus, central banks in developing countries are adopting inflation targeting (IT), which is founded on the tenets of the NCM. 
Inflation targeting intrinsically requires central banks to be highly averse to inflation or at least reputably more inflation averse than political policymakers. For developing countries, the inflation threshold which is the level beyond which inflation becomes harmful, is variously estimated at 11-18 per cent (Michael, 2012). In addition to countries already practicing formal Inflation targeting, a number of developing countries practice an implicit inflation targeting (Nigeria inclusive), while some adopts the explicit version within the medium term.

Inadequate knowledge of the economic system can deter policy actions from having the desired effects. Similarly, inadequate understanding of the consequences of monetary policy would lead to misjudgment and would substantially increase the costs of achieving any given goal. In Nigeria, uncertainty about the transmission mechanism and incomplete understanding of the system has remained a major challenge for monetary policy (Uchendu, 2009). This is compounded by the existence of a vibrant informal sector, the fabric of which remains largely indiscernible. Monetary policy in Nigeria is, therefore, undermined and characterized by uncertainty and inadequate knowledge (by policymakers and others) of the economy. These challenges are believed to contribute to volatility and slow economic growth (Greg, Udude \& Hope, 2015).

\section{Objectives of the Study}

Broadly, this study assesses the effect of monetary policy on economic growth in Nigeria. Specifically, the study:

i. $\quad$ Examine the impact of monetary policy on economic growth in Nigeria.

ii. Ascertain whether a long-run relationship exist between monetary policy and economic growth in Nigeria.

iii. Determine the nature of causation between monetary policy and economic growth in Nigeria.

\section{The New Consensus Macroeconomic}

\section{THEORETICAL FRAMEWORK}

An amalgamation of some of the key assumptions of the New-Classical (rational expectations) and the New-Keynesians (short-run rigidities and long-run flexibility) constitutes the bedrock of the NCM model, the policy conclusion of which is that price-stability is the main objective of monetary policy. According to Setterfield (2006), the key elements of the NCM model are the assumption of real wage bargaining, monetary neutrality, supply-driven equilibrium and demand-determined inflation. Following Clarida, Galí and Gertler (1999) and Meyer (2001), these elements are typically summarized by three equations; IS-type Aggregate Demand (AD), Phillips Curve (PC), and monetary rule (MR) - with micro-foundations in agents' optimization procedure (Gali, 2008). The views of the NCM are parallel to those of the New-Keynesians and New-Classical in arguing that a Central Bank cannot engage in real output stabilization in the long-run, since the combination of rational expectation and continuous market clearing ensures the emergence of inflationary pressures without output gains. The Central Bank should thus concentrate on long-run price-stability and short-run output stabilization (Fontana \& Palacio-Vera, 2007).

\section{Empirical Literature}

Ayodeji and Oluwole (2018) examined the impact of monetary policy on economic growth in Nigeria using annual time series data. The data covered the period of 1981-2016. The study used the vector error correction model (VECM) to carry out its analysis. Findings from the study revealed that two variables (money supply and exchange rate) had a positive but fairly insignificant impact on economic growth, while the interest rate and liquidity ratio on the other hand, had negative and highly significant impact on economic growth. 
Ufoeze, Odimgbe, Ezeabalisi and Alajekwu (2018) investigated the effect of monetary policy on economic growth in Nigeria. The study used annual time series data covering the period of 1986 to 2016. The study employed the Multiple regression to carry out the study. Findings of this study showed that the interest rate, and investment have insignificant positive effect on economic growth in Nigeria. Money supply however has significant positive effect on growth in Nigeria. Exchange rate has significant negative effect on GDP in Nigeria. Money supply and investment granger cause economic growth, while economic growth causes interest rate in Nigeria. On the overall, monetary policy explains $98 \%$ of the changes in economic growth in Nigeria.

Inam and Ime (2017) investigated the impact of monetary policy on the economic growth of Nigeria using annual time series data covering the period of 1970 to 2012. The study employed the Multiple regression analysis to carry out its analysis. The study finds a positive relationship between money supply which represented the policy variable in the study and economic growth in Nigeria, indicating that monetary policy increased growth by 42 per cent.

Okwori and Abu (2017) examined the efficacy of monetary policy in curbing inflation in Nigeria. Time series data from the CBN annual publication covering the period between 1986 and 2015 were used and the Vector Error Correction Model (VECM) was employed to carry out the study. The study found out that monetary policy is significant in curbing inflation threshold in Nigeria, however the effect of monetary policy variables are weak in controlling inflation. This is as a result of the large proportion of informal sector which culminates into a high currency outside bank economy that is largely not affected by monetary policy tools.

Thao (2017) evaluated monetary policy operation in Vietnam between 1998-2016. The study employed the Structural VAR to carry out the analysis. The study used monthly data spanning 1998M1-2016M12. Findings revealed that money supply, domestic credit aggregate, and exchange rate all had significant effect on output level. But however, the credit channel was found to have an important role in monetary transmission mechanism, while interest rate might not be the main instrument of the central bank to control inflation.

Nasko (2016) examined the impact of monetary policy on economic growth in Nigeria. The study used time-series data covering a period of 1990 to 2010. In conducting the analysis, the Multiple regressions was employed to carry out the study. The policy variables of the study were money supply and interest rate. Findings of the study revealed that interest rate had an average 0.16 declines on growth holding other factors constant. Also money supply also had a negative impact on economic growth. The results showed that various monetary policies administered through those variables have not probably been adequately applied to help propel growth.

Celina (2014) examined the impact of monetary policy on the growth of Nigeria economy between the period of 1981 and 2012 with the objective of finding out the impact of various monetary policy instruments (money supply, interest rate, exchange rate and liquidity ratio) in enhancing economic growth of the country within the period considered. The study employed the Vector Error Correction Mechanism (VECM) for its analysis. Findings indicated that only exchange rate exerted significant impact on economic growth in Nigeria while other variables did not. Equally, only money supply though statistically insignificant possessed the expected sign while others contradicted expectation. The study concluded that monetary policy did not impact significantly on economic growth of Nigeria within the period under review and that the inability of monetary policies to effectively maximize its policy objective most times is as a 
result of the shortcomings of the policy instruments used in Nigeria as such limits its contribution to growth.

Mustafa (2013) empirically examined the effects of monetary policy on macroeconomic performance in Nigeria spanning a period of 1970 to 2011. The study employed quarterly data sourced from the CBN annual statistical bulletin. It employed Structural Vector Autoregressive (SVAR) econometrics model to trace the effects of monetary policy shocks on domestic output, consumer price index and balance of payment position in Nigeria. Findings from the study are that monetary policy in Nigeria is effective in maintaining internal balance and ineffective in achieving external balance.

Employing the New Consensus Macroeconomics framework, Michael (2012) using the ARDL model, evaluated monetary policy in developing countries taking Nigeria as a case study. It used quarterly data spanning 1985:Q1 to 2011:Q2. It examined an array of market, retail deposit and lending rates. Also, the effect of monetary policy on aggregate demand is investigated, since it constitutes the intermediate target of policy; it used monetary policy rate, inflation, private sector credit and GDP as variables. Results indicated that an NCM-type monetary policy is generally ineffective in anchoring interest rates or aggregate demand and may be conducted at a considerably high cost in terms of output loss and financial instability. Hence, to avert the associated problems, there is a need for other instruments which the central bank can control effectively.

Mugume (2011) examined the effectiveness of monetary policy transmission in Uganda to analyze the dynamic effects of monetary policy shocks using monthly data covering 2000:M12010:12. The study employed the structural vector autoregressive (SVAR) approach to find the effects of monetary policy innovations on output proxy by GDP and inflation proxy by consumer price index. The results of the estimated impulse-response functions are overall consistent with economic theory. Following a contractionary policy shock, the short-term interest rate rises, leading to fall in output, consumer's price level, and the local currency appreciates. also, shocks to $M_{2}$ have no significant effect on domestic output growth and inflation and monetary policy seem to have no significant effect on domestic credit. Although domestic credit innovations significantly raise inflation, the exchange rate and credit channels seem to be ineffective.

This study uniquely departs from previous studies in that it adopted the NCM framework, and employed the monetary policy rate (MPR) (which is an important variable in the IT framework in Nigeria) to capture monetary policy. Noteworthy, is the fact that the work Michael (2012) particularly employed the NCM framework, and adopted the ARDL framework, the scope of the study however terminated at 2011.

\section{METHODOLOGY}

This study used secondary data in its analysis. In particular, it employed quarterly time series data, spanning the period of 1986:Q1 to 2018:Q4. The Autoregressive Distributed Lag (ARDL) model was used to carry out the $1^{\text {st }}$ and $2^{\text {nd }}$ objectives of this study. The choice of this methodology stems from the fact that the ARDL procedure can establish a long-run relationship whether the variables are I(0) or I(1) or whether the order of integration is mixed.

\section{Model Specification}

To carry out the empirical analysis, the study adapted the work of Michael, C.0. (2012); as such, the functional and econometrics forms of the model are given in Equation [1] and Equation [2] respectively; 


$$
\begin{aligned}
& G D P=f\left(M P R, M_{2}, I N F\right) \\
& L n G D P_{t}={ }_{0}+{ }_{1} \operatorname{LnMPR}_{t}+{ }_{2} \operatorname{LnM}_{2 t}+{ }_{3} \operatorname{LnINF}_{t}+{ }_{t}
\end{aligned}
$$

Apriori Expectation: $L n G D P, \operatorname{Ln} M P R, \& \operatorname{Ln} M_{2}>0$, while $I N F<0$

Where, ${ }_{0}$ is the intercept; ${ }_{1},{ }_{2}$ and ${ }_{3}$ are the coefficients of the variables; ${ }_{t}$ represents the error term, $L n G D P_{t}$ represents the natural $\log$ of real gross domestic product, $M P R_{t}$ is the natural $\log$ of the monetary policy rate, $\operatorname{Ln}_{2 t}$ represents the natural $\log$ of broad money supply, while $L n I N F_{t}$ represent the natural log inflation rate.

\section{Estimation Procedure}

\section{Unit Root Test}

This study used the Augmented Dickey-Fuller test (ADF) to carry out its unit root test. The Augmented Dickey-Fuller test (ADF) tests the null hypothesis that a unit root is present in a time series sample. The alternative hypothesis is different depending on which version of the test is used, but is usually stationary or trend-stationary. It is an augmented version of the Dickey-Fuller test.

\section{The ARDL Approach to Cointegration}

The ARDL bounds test procedure for examining the impact of monetary policy on economic growth in Nigeria is given by Pesaran, Shin and Smith (2001). In tune with the ARDL approach, Equation [2] is specified as:

$$
\begin{aligned}
& \operatorname{LnGDP_{t}=}{ }_{0}+{ }_{1} \operatorname{LnGDP}_{t 1}+{ }_{2} \operatorname{LnMPR}_{t 1}+{ }_{3} \operatorname{LnM}_{2 t}+{ }_{4} I N F_{t 1} \\
&+{ }_{t=0}^{p} \operatorname{LnGDP}_{t 1}+{ }_{t=0}^{p} \operatorname{LnMPR}_{t 1_{1}}+{ }_{t=0}{ }_{3} \operatorname{LnM}_{2 t 1} \\
&+{ }_{t=0}^{p}{ }_{4} \operatorname{LnINF}_{t 1_{1}}+{ }_{t}
\end{aligned}
$$

where, ${ }_{1}$ to ${ }_{4}$ are the long-run multipliers, ${ }_{0}$ is the drift and ${ }_{t}$ are white noise errors. Following these specifications, the test for cointegration is carried out using the F-test. When the F test has been calculated it is then compared with the critical values tabulated by Pesaran, Shin and Smith (2001) for very large samples or by Narayan (2004) for small samples. The lower critical bound assumes that all variables are $\mathrm{I}(0)$ meaning that there is no cointegration among the variables. The upper bound assumes that all the variables are I(1).

As a decision rule, If the $F$-statistics value lies above the bound of critical value, the null hypothesis is rejected. If the $F$-statistic value falls below the lower bound of critical value, the null hypotheses cannot be rejected that is, there is no long run relationship among the variables, however, if the $F$-statistic value lies within the bound test the result is inconclusive.

The hypothesis for testing the existence of cointegration among the economic growth determinants is such that the:

Null hypothesis of the base model, $H_{0}$ :

$H_{0}:{ }_{1} \quad 2 \quad 3 \quad{ }_{4} \quad 0$

Is tested against the alternative hypothesis $H_{1}$ :

$H_{1}:{ }_{1}={ }_{2}={ }_{3}={ }_{4}=0$ 
Once cointegration is established, the next step involves the estimation of the long- run and short-run relationships. The long-run model to be estimated is as follows:

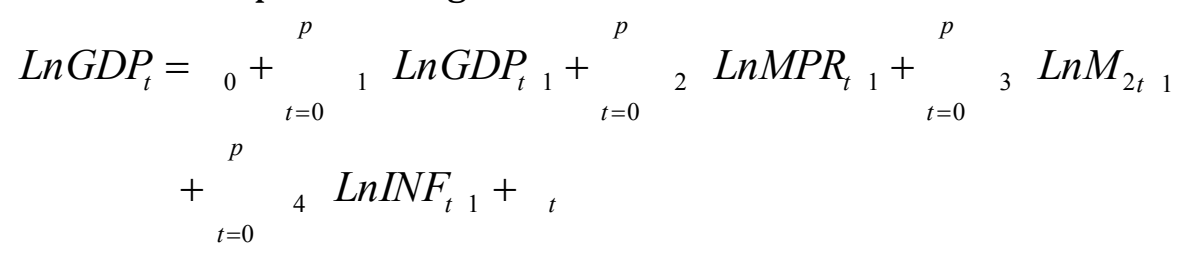

The SIC selects the appropriate orders of the ARDL model as such information criteria is described as more parsimonious with the lag length selection and is a consistent model selection criterion, and hence more reliable in small samples (Peasaran \& Shin 1999). The specifications above represent only the long-run equilibrium state of economic growth determinants. However, for policy purposes, the short-run adjustment of economic growth is also necessary. To account for the speed of adjustment, a dynamic error correction model is further specified.

The specification for the short-run dynamic parameters estimated by the error correction model is specified as follows:

$$
\begin{aligned}
\operatorname{LnGDP_{t}} & ={ }_{0}+{ }_{t=0}^{p} \operatorname{LnGDP}_{t 1}+{ }_{t=0}^{p}{ }_{2} \operatorname{LnMPR}_{t 1}+{ }_{t=0}^{p} \operatorname{LnM}_{2 t 1} \\
& +{ }_{t=0}^{p}{ }_{4} \operatorname{LnINF}_{t 1}+\operatorname{ECM}_{t 1}+{ }_{t}
\end{aligned}
$$

where, ${ }_{1}$ to ${ }_{4}$ are the short-run dynamic coefficients of the model's convergence to equilibrium, and is the speed of adjustment. The ECM term in the error correction representation also confirms the existence of cointegration/long-run relationship among the variables when this term is negative and statistically significant.

This long-run and short-run estimation is of most importance in this technique, as it is on the basis of this that inference can be drawn as to whether monetary policy has a significant impact on economic growth in Nigeria.

\section{Causality Test}

For the $3^{\text {rd }}$ objective, the Granger causality test is employed. Causality in the sense defined by Granger (1969) is inferred when lagged values of a variable, say $X_{t}$, have explanatory power in a regression of a variable $Y_{t}$. If a pair of variables are cointegrated, there must be Granger causality in at least one direction, which reflects the direction of influence between series. The basic empirical question in this study is whether monetary policy affects economic growth in Nigeria. Theoretically, if the current or lagged terms of a variable, for example $X_{t}$, determine another variable, for example $Y_{t}$, then there exists a granger causality relationship between $X_{t}$ and $Y_{t}$, in which $Y_{t}$ is granger caused by $X_{t}$.

\section{Residual Diagnostic Tests}

The study used the Breusch-Godfrey serial correlation LM test to test for serial correlation, and also employed the Cumulative sum of recursive residuals (CUSUM) and Cumulative sum of squares of recursive residuals (CUSUMSQ) to test the validity of the ARDL model: 


\section{Stationarity Test Results}

\section{PRESENTATION AND ANALYSIS OF RESULT}

The Augmented Dickey Fuller (ADF) unit root test on Appendix 1 was carried out to ensure that none of the variables included in the model is non-stationary, and to determine the order of integration of the variables.

The results of stationarity test indicated that three of the series were integrated at order one; that is GDP, MPR, and $\mathrm{M}_{2}$, while INF was stationary at level. Therefore, the order of Stationarity is mixed and this made ARDL an appropriate modelling technique.

\section{The Autoregressive Distributive Lag (ARDL) Model Analysis}

The ARDL optimal model as given by the Eviews 10 result is $(1,0,0,4)$ and it is used to determine the impact of monetary policy on economic growth in Nigeria.

\section{The ARDL Bound Test}

The ARDL bound test which establishes the existence of co-integration in the ARDL model is presented on Appendix 2.

The Bounds test result on Appendix 2 showed that the F-statistics value is 10.29. This value is greater than the upper bound critical values of I(1) at all the levels of significance. This result therefore showed the existence of long-run relationship in the model, and as such the study proceeded to conduct the short-run and long-run forms of the ARDL model.

\section{ARDL Long-Run Result}

The ARDL long-run result on Appendix 3 shows the nature of the relationship among the variables in the long-run.

The long-run coefficient of MPR indicated that the monetary policy rate instrument increased economic growth by 45\%, but it was however not statistically significant. The broad money supply $\left(M_{2}\right)$ as a monetary policy instrument increased economic growth by $91 \%$ and was also highly statistically significant. This finding was in consonance with other studies like Ufoeze, Odimgbe, Ezeabalisi and Alajekwu (2018) and that Inam and Ime (2017) which revealed that money supply was a much more viable monetary policy instrument, in comparison to the MPR. The coefficient of inflation rate which represented the control variable in the model followed apriori expectation, as it retarded economic growth by $17 \%$.

\section{The Short-run Result}

The short-run model is as given on Appendix 4. The error correction term of -0.12 was not only negative but also statistically significant confirming the existence of short-run relationship in the ARDL model. This also confirmed the existence of a long-run relationship between GDP and its regressors. The ECM measures the speed of adjustment back to equilibrium following a shock in the system. In this case approximately $12 \%$ cent of disequilibria is corrected quarterly in the model. This showed a low speed of adjustment.

\section{Test of Causality}

The Granger causality test was used to determine whether there exists a causal relationship between monetary policy and economic growth in Nigeria. The result is presented on Appendix 5.

The result of the Granger causality test showed that out of the two monetary policy instrument of monetary policy rate $(M P R)$ and broad money supply $\left(M_{2}\right)$, only broad money supply 
granger caused economic growth at the 10\% level of significance. The broad money supply $\left(M_{2}\right)$ also granger caused inflation rate. The result of the Granger causality test supports the result of the ARDL long-run model, and concluded that the broad money supply $\left(M_{2}\right)$ was a superior monetary policy instrument to achieve economic growth and control inflation.

\section{Residual Diagnostic Test}

Serial Correlation Test Result

The result of the Breusch-Godfrey serial correlation LM test on Appendix 6 accepted the null hypothesis of no serial correlation in the residual, since the probability of its F-statistic value of $45 \%$ cent was greater than the $5 \%$ level, thus concluding that the ARDL model does not have the problem of serial autocorrelation.

\section{Stability Test Result}

The result of the Cumulative sum of recursive residuals (CUSUM) and the Cumulative sum of squares of recursive residuals (CUSUMSQ) tests are presented on Appendix 7 and Appendix 8 respectively.

From Appendix 7, it was observed that the plots of CUSUM statistic crossed the critical value line indicating some instability in the model. However, the instability that was observed in the $4^{\text {th }}$ quarter of 2007 became stable in the $4^{\text {th }}$ quarter of 2013 as such bringing the plot of CUSUM statistic within the critical value bounds. As further confirmation, the result of the CUSUMSQ in Appendix 8 were all within the two straight line indicating that the ARDL model was stable.

\section{RECOMMENDATIONS}

The study recommends that there is the need for the Central Bank of Nigeria (CBN) to embark on a comprehensive monitoring of monetary instruments and aggregates and place less emphasis on Inflation Targeting (IT) alone. It is important to combine other instruments which the central bank can control effectively like the broad money supply $\left(M_{2}\right)$ as it is more effective. Effective monetary policy implementation should combine money supply based anchors while controlling and manipulating instruments such as short-term interest rate and the lending rates as it is a major tool for transmitting monetary policy impulses for economic performance in the Nigerian economy.

\section{CONCLUSION}

This study concluded that monetary policy had a positive and significant impact on economic growth in Nigeria for the period under analysis. The use of inflation targeting monetary policy $(M P R)$ although had a positive impact on economic growth, it however was insignificant in comparison with the use of money supply which was highly statistically significant at increasing economic growth. The study also concluded that money supply was also an effective monetary policy tool for controlling inflation, noting that the Granger causality test revealed causation running from $M_{2}$ to inflation rate as well as economic growth. This finding was in consonance with other studies like Ufoeze, Odimgbe, Ezeabalisi and Alajekwu (2018) and that Inam and Ime (2017) which revealed that money supply was a much more viable monetary policy instrument in the economy. 


\section{References}

Arestis, P. (2007). What is the new consensus in macroeconomics? in Arestis, P. (ed.) Is there a new consensus in macroeconomics? Hampshire: Palgrave Macmillan.

Ayodeji, A., \& Oluwole, A. (2018). Impact of Monetary Policy on Economic Growth in Nigeria. Open Access Library Journal, 5, 1-13.

Bean, C. (2007). Is there a new consensus in monetary policy? in P. Arestis (Ed.) Is there a New Consensus in Macroeconomics? Hampshire: Palgrave Macmillan.

CBN (2018). Monetary policy. Central Bank of Nigeria. Retrieved from https://www.cbn.gov.ng/monetarypolicy/conduct.asp

Celina, U.C. (2014). Monetary policy and economic growth of Nigeria. Journal of Policy and Development Studies, 9(1), 234-247.

Chand, S. (2018). The major role of monetary policy in a development economy. Your Article Library. Retrieved from http://www.yourarticlelibrary.com/economics/money/the-major-role-of-monetary-policy-in-adevelopment-economy-economics/11025

Clarida, R.J. Galí, R. \& Gertler, M. (1999). The science of monetary policy: A new keynesian perspective. Journal of Economic Literature, 37(4), 61-70.

Fontana, G. \& Palacio-Vera, V. (2007). Are long-run price stability and short-run output stabilisation all that monetary policy can aim for? Metroeconomica, 58(2), 269-98.

Fontana, G. (2009). Whither new consensus macroeconomics? The role of government and fiscal policy in modern macroeconomics: in Hein, E., Niechoj, T. \& Stockhammer, V. (Eds.) Macroeconomic policies on shaky foundations whither mainstream economics? Marburg: Metropolis-Verlag.

Greg, E.E., Udede, C.C. \& Hope, I.U. (2015). The impact of monetary policy on the banking sector in Nigeria. International Journal of Economics, Commerce and Management, 3(5), 1015-1035.

Inam, U.S., \& Ime, B.S. (2017). Monetary policy and economic growth in Nigeria (1970-2012). Advances in Social Sciences Research Journal, 4(6), 41-59.

Meyer, L.H. (2001). Does money matter? Federal reserve bank of St. Louis: Review, 83(5), 1-16.

Meyer, L.H. (2001). Does money matter? Federal reserve bank of St. Louis: Review, 83(5), 1-16.

Michael, C.O. (2012). Monetary policy in developing countries: The case of Nigeria (Doctoral dissertation). University of Leeds, Leeds University Business School.

Michael, C.O. (2012). Monetary policy in developing countries: The case of Nigeria (Doctoral dissertation). University of Leeds, Leeds University Business School.

Mugume, A. (2011). Monetary transmission mechanism in Uganda. Final Report, AERC Working Paper, Nairobi, Kenya, JEL Classification Numbers: 053, E4, E5

Mustafa, I. (2013). Effects of monetary policy on macroeconomic performance: The case of Nigeria (Doctoral dissertation). University of Greenwich, London.

Nasko, A.M. (2016). Impact of monetary policy on the economy of Nigeria. Pyrex Journal of Business and Finance Management Research. 2(10), 163-179.

Okwori, J., \& Abu, J. (2017). Monetary policy and inflation targeting in Nigeria. International Journal of Economics and Financial Management, 2(3), 1-12.

Setterfield, M. (2006). Is inflation targeting compatible with post-Keynesian economics? Journal of Post Keynesian Economics, 28(4), 653-671.

Thao, B.T.N. (2017). An evaluation of monetary policy in Vietnam (Master's thesis). School of Business, Aalto University, Vietnam.

Uchendu, O.A. (2009). Monetary policy management in Nigeria in the context of uncertainty. Bullion, Central Bank of Nigeria, 33(3), 1-6.

Ufoeze, L.O., Odimgbe, S.O., Ezeabalisi, V.N., \& Alajekwu, U.B. (2018). Effect of monetary policy on economic growth in Nigeria: An empirical investigation. Annals of Spiru Haret University Economic Series, 1, 2018, 123-140. 


\section{APPENDICES}

Appendix 1: PP Unit Root Tests Results

\begin{tabular}{|c|c|c|c|c|}
\hline Variable & Order & PP Calculated & PP Critical Value & Conclusion \\
\hline \multirow[t]{2}{*}{$G D P$} & At levels & -2.252953 & -3.444487 & $1(1)$ \\
\hline & $1^{\text {st }}$ difference & -12.74361 & -3.444756 & \\
\hline \multirow[t]{2}{*}{$M P R$} & At levels & -2.659068 & -3.444487 & $1(1)$ \\
\hline & $1^{\text {st }}$ difference & -11.36157 & -3.444756 & \\
\hline \multirow[t]{2}{*}{$M_{2}$} & At levels & -0.704610 & -3.444487 & $1(1)$ \\
\hline & $1^{\text {st }}$ difference & -12.08161 & -3.444756 & \\
\hline$I N F$ & At levels & -3.792454 & -3.444487 & $1(0)$ \\
\hline
\end{tabular}

Appendix 2: ARDL Bound Test Result

\begin{tabular}{lcccc}
\hline F-Bounds Test & \multicolumn{4}{c}{ Null Hypothesis: No levels relationship } \\
\hline Test Statistic & Value & Signif. & I(0) & I(1) \\
F-statistic & 10.28703 & $10 \%$ & 2.37 & 3.2 \\
K & 3 & $5 \%$ & 2.79 & 3.67 \\
& & & 3.15 & 4.08 \\
& & $1 \%$ & 3.65 & 4.66 \\
\hline
\end{tabular}

Appendix 3: ARDL Long-run Result

\begin{tabular}{crrrr}
\hline Variable & Coefficient & Std. Error & t-Statistic & Prob. \\
\hline LnMPR & 0.449259 & 0.298216 & 1.506487 & 0.1346 \\
LnM2 & 0.908935 & 0.098824 & 9.197475 & 0.0000 \\
LnINF & -0.170540 & 0.225992 & -0.754629 & 0.4520 \\
C & 0.917228 & 0.992119 & 0.924514 & 0.3571 \\
\hline
\end{tabular}

Appendix 4: Short-run ARDL Model Coefficients

\begin{tabular}{crrrr}
\hline \multicolumn{5}{c}{ Cointegrating Form } \\
\hline Variable & Coefficient & Std. Error & t-Statistic & Prob. \\
\hline D(LNINF) & -0.037795 & 0.043466 & -0.869550 & 0.3863 \\
D(LNINF(-1)) & 0.040738 & 0.043299 & 0.940838 & 0.3487 \\
D(LNINF(-2)) & -0.005082 & 0.043221 & -0.117573 & 0.9066 \\
D(LNINF(-3)) & -0.206231 & 0.043186 & -4.775376 & 0.0000 \\
CointEq(-1)* & -0.115130 & 0.015790 & -7.291370 & 0.0000 \\
\hline
\end{tabular}


Appendix 5: Granger Causality Test Result

\begin{tabular}{lccc}
\hline Null Hypothesis: & Obs & F-Statistic & Prob. \\
\hline LnMPR does not Granger Cause LnGDP & \multirow{2}{*}{130} & 0.21263 & 0.8088 \\
LnGDP does not Granger Cause LnMPR & & 1.04086 & 0.3562 \\
LnM $_{2}$ does not Granger Cause LnGDP & 130 & 2.56999 & 0.0806 \\
LnGDP does not Granger Cause LnM & & 1.26104 & 0.2869 \\
LnINF does not Granger Cause LnGDP & 130 & 0.35961 & 0.6987 \\
LnGDP does not Granger Cause LnINF & & 2.84741 & 0.0618 \\
LnM 2 does not Granger Cause LnMPR & 130 & 1.37102 & 0.2576 \\
LnMPR does not Granger Cause LnM2 & & 1.23116 & 0.2955 \\
LnINF does not Granger Cause LnMPR & 130 & 0.85742 & 0.4267 \\
LnMPR does not Granger Cause LnINF & & 19.9005 & $3 . \mathrm{E}-08$ \\
LnINF does not Granger Cause LnM & \multirow{2}{*}{130} & 0.23014 & 0.7948 \\
LnM $M_{2}$ does not Granger Cause LnINF & & 3.06924 & 0.0500 \\
\hline
\end{tabular}

Appendix 6: Breusch-Godfrey Serial Correlation LM Test Result

\begin{tabular}{llll}
\hline F-statistic & 0.810992 & Prob. F(2,117) & 0.4469 \\
Obs*R-squared & 1.750215 & Prob. Chi-Square(2) & 0.4168 \\
\hline
\end{tabular}

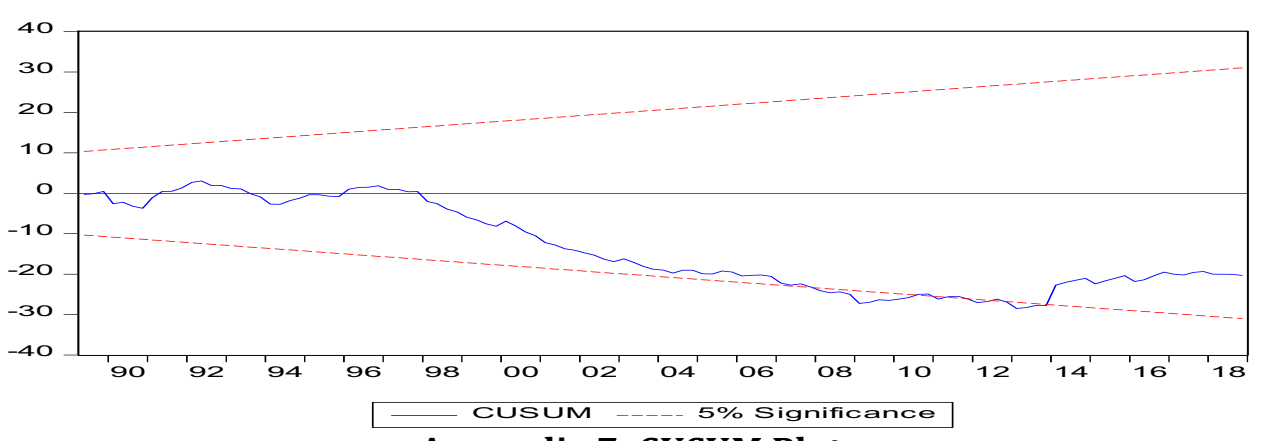

Appendix 7: CUSUM Plot

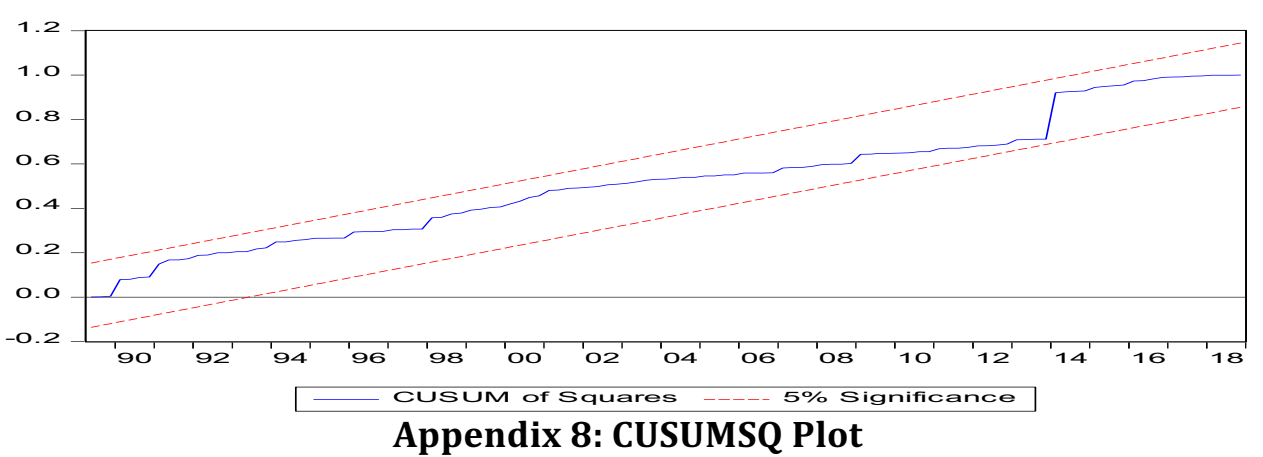

